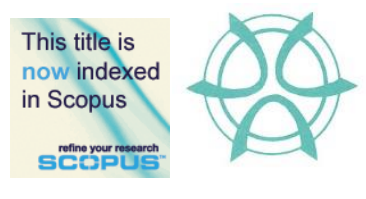

PLANNING MALAYSIA:

Journal of the Malaysian Institute of Planners

VOLUME 16 ISSUE 4 (2018), Page 104 - 116

\title{
EMERGING BUILT HERITAGE COMMODIFICATION OF BOUTIQUE HOTELS IN WORLD HERITAGE SITE: EVIDENCE FROM GEORGE TOWN, PENANG, MALAYSIA
}

\author{
Suraiyati Rahman ${ }^{1}$ \\ ${ }^{1}$ School of Housing, Building and Planning \\ UNIVERSITI SAINS MALAYSIA
}

\begin{abstract}
Although heritage, by its very nature, has been in existence for a long time, an understanding of the ways in which heritage products can be used is relatively recent. The increasing number of boutique hotels in George Town has contributed to the distinctiveness of lodging accommodation. In many cases, this has led to the commodification of the built historic environment and its history into a form of tourism product. This study sought to investigate the process of the built heritage commodification of boutique hotels in George Town. A semi-structured interview was conducted among boutique hotel managers and entrepreneurs in George Town, Penang. The findings revealed that external factors such as the global recognition of George Town as a World Heritage Site and the setting of the historic city are the pull factors for investors to purchase premises in the city centre. These built heritage resources (tangible heritage) and intangible values have been assimilated with their contemporary uses to be commodified into different types of boutique hotels. The attempt to establish a built heritage commodification model will contribute to the empirical data on the process and the factors that lead to the built heritage commodification of boutique hotels in heritage city.
\end{abstract}

Keywords: built heritage, boutique hotels, heritage commodification, World Heritage Site, tourism 
PLANNING MALAYSIA

Journal of the Malaysia Institute of Planners (2018)

\section{INTRODUCTION}

Heritage buildings, monuments and cultures are heritage resources that remind us of history and contribute to sense of place (Suraiyati, 2013). The concept of heritage has evolved from a focus on preservation to looking at the practice and adoption of contemporary needs. Recently, historical resources have been used widely to shape the socio-cultural identity of places. Heritage commodification is the process of transforming historic resources into a contemporary commodity to satisfy a current consumption need. Yet, there is limited understanding of the process of heritage as used in the context of tourism. Theoretically, the heritage production model suggested by Ashworth and Larkham (1994) is mainly based on the existence of resources. Culture and heritage are common attractions for cultural tourists, who seek authenticity and an experience of the past. Experiencing heritage has become one of several priorities in the cultural motivation to travel, resulting in a commodification of the past (Waitt, 2000; Amir, Osman, Bachok, Ibrahim, \& Mohamed, 2017). According to Ashworth (2012), the built environment resulted from human needs, and this can be seen in the physical morphologies and usage of the physical environment (Rani, Putri, \& Devina, 2017). He added, as contemporary requirements change, the forms to accommodate those requirements will consequently be transformed.

The trend to protect historic buildings and monuments, and to preserve, conserve and re-adaptive use, has been extensively discussed and practised. However, the response of the market towards the heritage tourism industry has boosted the opportunity to commodify heritage resources into profitable products. Heritage commodification is a newly-introduced term, yet it has been in practice due to market demand. The conversion of built heritage resources into heritage products can generate economic income, conserve heritage resources and educate the society on the values of history (Astuti, Permana, Qomarun, Febela, \& Andisetyana, 2017). Wight (1994) claimed that a destination with maximum business goals of tourism development but few strategies for cultural heritage conservation might lead to the loss of its culture and tradition. Similarly, Li (2003) stated that intensified efforts to conserve a cultural heritage rather than to develop it for tourism may lead to the failure of businesses in a destination. The scenario of a market driven by tourism development can be seen in Malaysia, especially in George Town and Melaka, due to the World Heritage listing inscription. George Town is known as a popular destination because of its local culture and heritage characteristics, with its abundance of pre-war buildings and history.

The increasing number of boutique hotels in George Town has contributed to the distinctiveness of its lodging accommodation, and these serve as tourist attractions. Based on previous studies, scholars and researchers have identified boutique hotels across continents, including the United States of America (Anhar, 2001), the United Kingdom (Aggett, 2007; Lim \& Endean, 
Suraiyati Rahman

Emerging Built Heritage Commodification of Boutique Hotels in World Heritage Site: Evidence from George Town, Penang, Malaysia

2009), South Africa (Rogerson, 2010), Turkey (Erkutlu \& Chafra, 2005), Australia (Lwin \& Phau, 2013), Thailand (Rompho \& Boonitt, 2012), Malaysia (Arifin, Jamal, Aziz, \& Ismail, 2015; Khosravi, Malek, \& Ekiz, 2014; Goh, 2015) and Singapore (Chang \& Teo, 2008; Henderson, 2011). Definitions for boutique hotels differ based on different characteristics such as the concept and architectural design, which vary from a unique architectural, modern, minimalist or heritage design. Heritage hotels are small in size, with the number of rooms being limited to not more than 100 rooms. They offer personalised service, and focus on a target market (Aggett, 2007; Lim \& Endean, 2009). Henderson (2011) also noted that boutique-style hotels are becoming increasingly popular in Southeast Asia, especially in heritage areas. However, research on the emerging commodification of built heritage into boutique hotels in Malaysia is relatively new. Hence, this article was aimed at examining the perspective from the supply side of investors and managers on the interpretation of the boutique hotel concept and the factors that contribute to the re-adaptation of heritage buildings into boutique hotels.

\section{LITERATURE REVIEW}

\section{Characteristics of Boutique Hotels}

The terminology of boutique hotels is broad and has been evolving since the 1980s. The many definitions of boutique hotels have led to difficulties in defining and conceptualising boutique hotels. The term 'boutique' itself refers to exclusiveness. However, this exclusiveness does not necessarily signify something that is expensive and that caters to the elite. The niche product in the hospitality industry, which is more geared towards distinctiveness and uniqueness, has led to the growing number of boutique hotels. The new consumer trend, which rejects the homogeneity that characterises the commercial accommodation sector, has given rise to the increasing number of boutique hotels (Aggett, 2007; Rogerson, 2010; Timothy \& Teye, 2009). A growing interest in art, culture and history, which started in 1980, is the underlying factor that has contributed to the acknowledgement of cultural tourism (Freund de Klumbis \& Munsters, 2005). The first boutique hotel, which was Morgan's Hotel in New York, was introduced in 1984. It was owned by Ian Schrager and Steve Rubell (Freund de Klumbis \& Munsters, 2005).

The key characteristics of a boutique hotel are quite subjective due to its broad terminology. A few scholars have suggested that these key characteristics are a small-sized property and limited rooms. Boutique hotels can accommodate a limited number of rooms at the same time (McIntosh \& Siggs, 2005; Wheeler, 2006; Lim \& Endean, 2009). A typical boutique hotel is associated with a smallscale property having between 50-100 rooms (Erkutlu \& Chafra, 2005; Van Hartesvelt, 2006; Agget, 2007; Lim \& Endean, 2009). Therefore, the number of 
guests in boutique hotels is less due to the limited capacity, essentially providing more individualised and personalised services compared to conventional hotels (McIntosh \& Siggs, 2005). The interaction between guests and the staff is more intimate compared to typical hotels, which are mass consumers. Boutique hotels have a high staff-to-guest ratio, thereby allowing them to provide personalised services (Lim \& Endean, 2009; Erkutlu \& Chafra, 2005) that enable each guest to experience a special and unique feeling throughout their stay.

Most of the boutique hotels are in city centres and are very popular among business travellers (Lim \& Endean, 2009; Albazzaz et al., 2003; Teo \& Yeh, 1997). Besides, the concept of boutique hotels has also been introduced in rural and suburban settings. Boutique hotels are typically referred to as nonstandardised hotels due to their unique design. This was supported by Forgsgren and Franchetti (2004), who stated that the purpose of hotels with a unique concept such as boutique hotels is to differentiate themselves from their competitors through their image, lifestyle, design and style.

Most of the boutique hotels are typically housed in older and unique structures that have been converted to new functions (Van Hartesvelt, 2006). The themes for boutique hotels range from heritage to contemporary, and modern. The aim is to offer an alternative option to chain hotels with a different look and ambience. Another characteristic of boutique hotels is their unique interior design. Lim and Endean (2009) added that "individuality" is the key term in describing the dissimilar design of each room in boutique hotels. For example, the decoration of each room might be based upon the works of a well-known painter (Lim \& Endean, 2009; Erkutlu \& Chafra, 2005). 'Warmth', 'intimacy', 'distinction' and 'stylish' are the most important key words that describe the architecture and design of boutique hotels. Generally, the room rate per night depends on the type of room.

The prices at boutique hotels vary and correspond to those of three to five-star hotels (Van Hartesvelt, 2006; Henderson, 2011). It is the exclusiveness of the price offered by boutique hotels that makes these hotels give more attention to the privacy of the guest. The table below shows the classification of the characteristics in a town setting.

\section{METHODOLOGY}

This research adopted a qualitative approach by conducting a content analysis of a literature review and semi-structured interview with hoteliers of boutique hotels in George Town, Penang. The purposive sampling technique was adopted in the qualitative studies by selecting units such as individuals, groups of individuals, and institutions with specific purposes that were able to answer the research questions. The key characteristics of boutique hotels in a heritage city were defined and identified in the case study area. Eighteen boutique hotels were identified in George Town, Penang based on the list given by the Ministry of 
Suraiyati Rahman

Emerging Built Heritage Commodification of Boutique Hotels in World Heritage Site: Evidence from George Town, Penang, Malaysia

Culture, Arts and Tourism, as well as a critical review of the characteristics of boutique hotels. The identified boutique hotels that are located within the core zone and buffer zone are shown in Figure 1. However, only 8 managers of the 18 boutique hotels agreed to participate in the interview. The responses were transcribed and analysed using a thematic analysis to identify the characteristics of a boutique hotel in the case study area as well as to establish a boutique hotel commodification model in the historic city.

\section{FINDINGS AND DISCUSSION}

\section{Emergence of Boutique Hotel Commodification in Heritage City}

Historically, George Town is a vibrant trading port with multi-ethnic inhabitants. The collection of pre-war buildings representing different periods and cultures has flourished to promote George Town as a heritage destination with a unique cultural image among tourists and visitors. However, it cannot be denied that the changing nature of the local residents, who are not keen to reside in the inner city of George Town compared to a few decades ago, has led to a change in the functional structure of the residential houses in the inner city of George Town. This has led to a re-adaptive use of the colonial premises in the inner city of George Town, where they are being converted for contemporary uses. Although the original functions of the premises might not be doable for the present day, but the attempt to conserve the pre-war premises might revitalise the heritage city and generate the economy. The emergence of boutique hotel commodification in George Town is caused by several factors, both extrinsic and intrinsic, that have contributed to the potential of new heritage business products in the World Heritage Site of George Town.

\section{Branding Image as World Heritage Site}

George Town possesses a distinctive character as a heritage city and was nominated as a World Heritage Site by UNESCO in 2008 under category II, III and IV, according to the Outstanding Universal Value (OUV). The world's recognition of the branding image of a heritage site has made it a popular destination for international and local tourists. Consequently, the demands of heterogeneous users have transformed the preservation of the built heritage. The establishment of boutique hotels started in George Town between 1999 and 2000, before George Town was inscribed as a World Heritage Site. There were initially only two boutique hotels, the Blue Mansion and Yeng Keng Hotel, which were operating until recently. The built heritage commodification of boutique hotels is an emerging phenomenon due to the market demand from a segmented group of users. Beginning 2008 onwards, entrepreneurs began to purchase premises in the city of George Town and converted their pre-war premises into classy and refined boutique hotels. The number of boutique hotels started to increase from 2008 
PLANNING MALAYSIA

Journal of the Malaysia Institute of Planners (2018)

onwards, until up to 16 boutique hotels had been established in George Town, Penang. The commodification process can be defined as the process of transforming goods, services or ideas into an extended economic value. R4 mentioned their decision to start a boutique hotel business in the inner city of George Town because "...this place is a good location (strategic location), where it is in the centre of George Town, a World Heritage Site...”. Similarly, with R1, R2, R3 and R6 ... "It is located within the heritage city of George Town....". R5 stated, "...this area is the core zone of heritage...". Most of the managers of boutique hotels stated that the World Heritage Site image and the core heritage zone were important factors for their initial motivation to set up their business. $\mathrm{Su}$ (2011) revealed that the commodification of urban heritage in Lijiang achieved great success in selling heritage to the tourism industry ever since it was designated a World Heritage Site in 1997. Nevertheless, George Town has inevitably shown an increase in the number of new investors who have adaptively re-used abandoned or old buildings for commercial purposes. The market demand has opened opportunities for contemporary uses for the hospitality industry.

\section{Multi-Functions of City Centre Setting}

Investors chose the location of the city centre of George Town as the city provides multiple functions and uses to tourists. Boutique hotels gain popularity in the city centre especially the heritage city. The city provides good transportation linkages with abundant facilities, various interesting places to visit, conveniences for pedestrians, and a setting for any art, music or cultural event or festival. From the findings, the location of the boutique hotels within the city centre comes with diverse amenities, facilities, local culture and accessibility to tourist attractions. R2, R3, R4, R5 and R8 had similar perspectives, whereby they indicated that their hotels were located in hotspots that were crowded with tourists. R2 stated, "It is located within the heritage city of George Town, and almost the entire hotel is crowded with people...", and R3 also stated, "The owner has found that this area is so crowded with people...". Meanwhile, R5 suggested that the location was “...very convenient for walking around to the places of attraction...". Location is not only a matter of convenience, but is also indicative of the 'trendiness' and 'chic-ness' of the respective neighbourhoods, which caused the hoteliers to locate their hotels within the city centre (Olga, 2009). Hence, the location of boutique hotels within city centres with vibrant economies and facilities provides a platform for producers (investors) to fully utilize the image branding of heritage sites for their consumers. This was supported by various authors (Teo \& Yeoh, 1997; Albazzaz et al., 2003; Lim \& Endean, 2009; Arifin et al., 2014), who stated that the strategic location of boutique hotels has become one of the key factors that can attract guests to stay. Hence, specialized lodgings like boutique hotels have been growing in the business area, which is in the most crowded place in the city. 
Suraiyati Rahman

Emerging Built Heritage Commodification of Boutique Hotels in World Heritage Site: Evidence from George Town, Penang, Malaysia

\section{Tangible Values: Distinctive Character of Historic Buildings}

George Town has the largest collection of pre-war premises in Southeast Asia, totalling approximately 4,000 premises. The conservation of historic buildings has become one of the approaches to prevent deterioration and to prolong the life of architectural buildings. Some of the owners are international investors, and they have developed the theme of a boutique hotel based on their interests. However, if the premises are under category I or II or are located within the core heritage zone, they are bound to comply with certain guidelines. In Malaysia, heritage buildings are protected under the National Heritage Act (2005), and any refurbishment and modification of the exterior façade and the interior are controlled by the local planning authority (Majlis Bandaraya Pulau Pinang) and a panel of conservation advisors. This is in line with the ideology of sustainability so as to preserve the historic value of a tangible heritage as an attraction in George Town since users of the niche market have started to appreciate the uniqueness and historic value of heritage buildings. According to the findings, quite a few respondents were aware of the guidelines for the protection of historic buildings. According to R1: “...We chose this location for our hotel so as to save a very important Grade 1 historic building....".

The Guidelines for Conservation Areas and Heritage Buildings (2011) describe category 1 buildings as buildings or monuments of exceptional interest that have been declared as being historical and are designated under the Antiquities Act (1979). These buildings must also be registered under the National Heritage Act (2005). Many of the boutique hotels, which are defined as being unique, both culturally and architecturally, fall under category 2. A category 2 building refers to a building that has special interest and warrants the making of every effort to preserve it. Investors make use of the existence of heritage buildings to transform them into boutique hotels. However, it is quite challenging to the investors to adapt the existing layout plan of a heritage building to convert it into a boutique hotel due to the protection guidelines. Most of managers stated that the pre-war premises offer a unique architectural design and layout.

\section{Intangible Values: Historical Elements Associated with Building Design, Location or Heritage Roots}

The history of Penang is revealed in its cultural diversification derived from the Europeans, Chinese, Indians, Bugis, Arabs, Armenians, Persians, Siamese, Burmese, and Sumatrans. The consolidation of these wide-ranging cultural influences has manifested itself in the interesting array of local cultures and histories that have influenced the architectural design of its buildings. Boutique hotels in George Town have diversified designs, with each room being individually decorated and furnished with a mix of antique and modern contemporary furnishings. Guests are offered the exclusiveness and rare 
PLANNING MALAYSIA

Journal of the Malaysia Institute of Planners (2018)

experience of enjoying different interior decorations. Typical city hotels normally categorise their various rooms based on the size such as deluxe, superior, family suite, and executive suite. However, the majority of the boutique hotels in George Town name their rooms according to themes. Some of the rooms refer to historical roots like The Liang Collection and The Tang Suites, while some hotels name their rooms according to the position of the room like the Air-Well Room, Balcony Room, and Courtyard Room. Some of the hotels name their rooms by referring to different types of spices like Ginger, Clove, Saffron, Star Anise, Cardamom, and Cinnamon. The content analysis from the secondary data (websites) provides the information in terms of the interior design of the room, pricing, name and characteristics of boutique hotels.

\section{Assimilation of Heritage Resources into the Characteristics of Boutique Hotels}

The number of rooms in boutique hotels in Georgetown range between 6 rooms to 45 rooms. There are 6 boutique hotels that have less than 10 rooms. The limited number of rooms is not only because of the special and distinctive boutique concept, but is also due to the design of the original buildings and the existing layout, which is quite narrow and with limited space. Most of the pre-war buildings in Georgetown are less than three-storeys high. The findings revealed that 6 units of boutique hotels had been transformed from residential houses into boutique hotels, while the rest of the hotels were originally commercial shop houses. The re-adapted old buildings have an interesting layout such as a courtyard and backyard with natural ventilation and lighting. Some of these buildings are Grade 1 Buildings, which pose a challenge to investors, who have to preserve the original condition of the architectural features. Henderson (2011) stated that heritage is a key element for boutique hotels in a city state, many of which are the result of the adaptive reuse of old buildings but are increasingly being combined with modern designs in many old buildings in Singapore. The same situation has occurred in George Town, Penang, where the themes of boutique hotels can be divided into 3 main themes, namely Mansions, Heritage and Modern Contemporary. These themes are based on the key features of the architectural style, the interior design, the furnishings, decorations and furniture. Only 2 boutique hotels, namely the Blue Mansion and Macalister Mansion, were converted from mansions into boutique hotels, while maintaining the name of the mansions for the hotels. Out of the remaining 16 boutique hotels, 10 of them emphasise the Heritage theme, while the other 6 represent the Modern Contemporary theme.

Boutique hotels offer a homely environment, with facilities such as a lobby, dining room, restaurant or cafe, living room, meeting room, private museum, swimming pool, mini gym, mini library and souvenir shop. Some of these hotels have an interesting layout like a courtyard and backyard with natural 
Suraiyati Rahman

Emerging Built Heritage Commodification of Boutique Hotels in World Heritage Site: Evidence from George Town, Penang, Malaysia

ventilation and lighting due to the original design of the premises. The most attractive attributes of the boutique hotels in George Town for guests are their specialised service, room features, convenience, and hotel design. Personal service was highlighted in the literature as being important in boutique hotels (McIntosh \& Siggs, 2005; Aggett, 2007; Lim and Endean, 2009; Khosravi, Malek, \& Ekiz, 2014). The decorations and layout of the hotel rooms and, particularly, the lobby, are an important component of the customer's experience during his/her stay in a boutique hotel (Aliukeviciute, 2011; McIntosh \& Siggs, 2005). Most of managers stated that the pre-war premises offer a unique architectural design and layout and require funding and innovation for refurbishment process. Investors make use of the existence of heritage buildings to transform them into boutique hotels. According to R1 and R8, “....it is quite challenging for the investors to adapt the existing layout plan of a heritage building to convert it into a boutique hotel due to the protection guidelines".

Table 1: Summary of boutique hotel characteristics in George Town

\begin{tabular}{|c|c|c|}
\hline & Attributes & Characteristics \\
\hline 1. & Size of the hotel & $\begin{array}{l}\text { Small size and limited number of } \\
\text { rooms of between } 6-45 \text { rooms. }\end{array}$ \\
\hline 2. & Location & $\begin{array}{l}5 \text { units in core zone, } 9 \text { units in buffer } \\
\text { zone and } 4 \text { units outside WHS. }\end{array}$ \\
\hline 3. & Architecture and design & $\begin{array}{l}\text { Pre-war buildings with unique } \\
\text { architecture; traditional shop houses, } \\
\text { and mansions. }\end{array}$ \\
\hline 4. & Theme & $\begin{array}{l}\text { Mansion, Heritage and Modern } \\
\text { Contemporary. }\end{array}$ \\
\hline 5. & Interior design/furniture & $\begin{array}{l}\text { Dissimilar designs and different sets } \\
\text { of furniture and decorations. }\end{array}$ \\
\hline 6. & Specialised service & $\begin{array}{l}\text { Level of service is more friendly, } \\
\text { personal and comfortable between } \\
\text { guests and staff of the hotels. }\end{array}$ \\
\hline 7. & Unique ambience & $\begin{array}{l}\text { The ambience in boutique hotels is } \\
\text { different and distinctive. }\end{array}$ \\
\hline 8. & Unforgettable experience & $\begin{array}{l}\text { The high level of service and a } \\
\text { homely environment create a rare and } \\
\text { unique experience for guests. }\end{array}$ \\
\hline 9. & Price & $\begin{array}{l}\text { Prices of boutique hotels depend on } \\
\text { their type and standard. }\end{array}$ \\
\hline
\end{tabular}

\section{Boutique Hotel Commodification Development Model}

This section describes the establishment of a model for boutique hotel commodification in a heritage town. A world-recognized branding image and strategic location in the city centre are the external factors that are considered by 
investors when deciding whether to initiate a business. The brand image of George Town as a World Heritage Site is a selling point for George Town as a heritage tourism destination, in addition to its other outstanding features and characteristics as a tourist spot. The uniqueness of heritage buildings, with their remarkable architectural designs, distinctive layout and historical value, is a key characteristic for their adoption for commodification as boutique hotels. Hence, old buildings like traditional shop houses and mansions are undergoing a process of adaptive reuse to be converted into boutique hotels. Investors will interpret their product in terms of their capacity to obtain funding, innovation and the creativity to commodify their existing resources and to assimilate them with the tangible and intangible values. The final products are commodified boutique hotels based on market demand. The limitations and challenges in the case of the listed buildings in the core zone have to do with obtaining the planning approval for refurbishment from the Majlis Bandaraya Pulau Pinang (MBPP). This built heritage commodification development model for boutique hotels possibly generalises the phenomenon of historic city with heritage buildings as their resources.
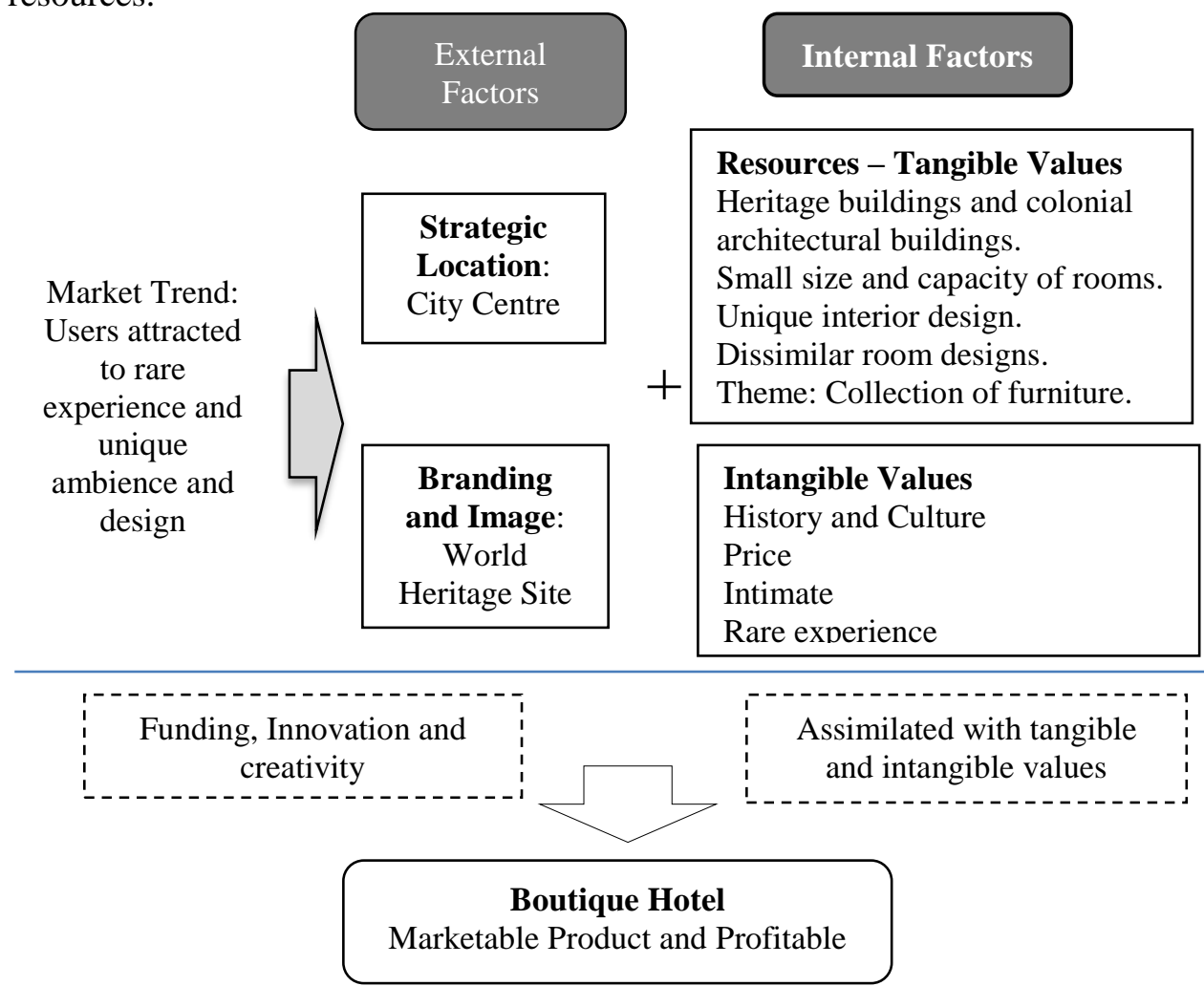

Figure 6: Model of boutique hotel commodification in Heritage Towns

Source: Author 
Suraiyati Rahman

Emerging Built Heritage Commodification of Boutique Hotels in World Heritage Site: Evidence from George Town,

Penang, Malaysia

\section{CONCLUSION}

Boutique hotels have a broad spectrum of characteristics, but in the case of George Town, eight main criteria have been identified, namely the size of the hotel, strategic location, distinctive architectural design, theme, dissimilar room designs, personalised service, rare experience and price. The potential of a branding image as a World Heritage Site and the multiple functions of a city centre are the external factors that contribute to the decision of investors to purchase pre-war premises for commodification into boutique hotels. The built heritage commodification depends on the intrinsic value of the heritage resources such as the unique architectural designs, distinctive layout, colonial premises, history and culture, and the collection of furniture. These resources will be assimilated with the intangible values and interpreted based on the innovation, funding and creativity. Investors of boutique hotels in George Town are mainly motivated by the making of profits and the revitalization of the built heritage. The case study of boutique hotels in George Town might not be the same for other urban settings. However, it can be concluded that the process of the commodification of built heritage may enhance the sustainability of the built heritage, but there may be a loss in authenticity due to the commercialisation of the product and market orientation. The issue of commodifying heritage may led to the loss of authenticity is supported by (Prideaux, 2003; Xu, Yan, \& Zhu, 2013; $\mathrm{Su}, 2011$; Terzano, 2014).

\section{ACKNOWLEDGEMENT}

The author(s) would like to extend their appreciation to the Ministry of Higher Education, Malaysia for granting the Fundamental Research Grant entitled 'Establishing an Interpretation Model of Built Heritage Commodification for Tourism in Georgetown, Penang' [Grant No. 203.PPBGN.6711405], which made this study possible.

\section{REFERENCES}

Aggett, M. (2007). What has influenced growth in the UK's boutique hotel sector? International Journal of Contemporary Hospitality Management, 19(2), 169-177.

Aliukeviciute, M. (2011). Boutique hotels evolution. Retrieved from https://ojs.kauko.lt/index.php/stmd/article/download/233/229

Albazzaz, A., Birnbaum, B., Brachfeld, D., Danilov, D., Kets de Vries, O., \& Moed, J. (2003). Lifestyles of the rich and almost famous: The boutique hotel phenomenon in the United States. Fontainebleau: Insead Business School.

Amir, S., Osman, M. M., Bachok, S., Ibrahim, M., \& Mohamed, M. Z. (2017). Tourism stakeholders perception on tourists' expenditure in entertainment sector in Melaka UNESCO World Heritage Area. Advanced Science Letters, 23(7), 63366338 . 
PLANNING MALAYSIA

Journal of the Malaysia Institute of Planners (2018)

Anhar, L. (2001). The definition of boutique hotels. Retrieved from http://www.hospitalitynet.org/news/4010409.html

Arifin, A. S., Jamal, S. A., Aziz, A. A., \& Ismail, S. S. (2015, September). A preliminary study on boutique hotels in the city of Kuala Lumpur. 2nd International Hospitality and Tourism Conference 2014. September 2-4, 2014, Penang, Malaysia.

Ashworth, G. J., \& Larkham, P. J. (1994). Building a new heritage: Tourism, culture and identity in the New Europe. London: Routledge.

Ashworth, G. J. (2012). Preservation, conservation and heritage: Approaches to the past in the present through the built environment. Journal Asian Anthropology, 10(1), $1-18$.

Astuti, W., Permana, A. S., Qomarun, Q., \& Andisetyana, R. (2017). Integrated planning model of creative industry-based kampung tourism in Jayengan Surakarta, Indonesia. Planning Malaysia, 15(3), 63-76.

Chang, T. C., \& Teo, P. (2008). The shophouse hotel: Vernacular heritage in a creative city. Urban Studies, 46, 341-367.

Erkutlu, H. V., \& Chafra, J. (2006). Relationship between leadership power bases and job stress of subordinates: Example from boutique hotels. Management Research News, 29(5), 285-297.

Freund de Klumbis, D. \& Munsters, W. (2005). Developments in the hotel industry. Design meets historic properties. Retrieved October 12, 2015, from http://bibemp2.us.es/turismo/turismonet1

Forsgren, S., \& Franchetti, C. (2004). The marketing role of unique concepts for hotels in Sweden: Tourism and hospitality management (Master Thesis No 2004: 53). Goteborg University, Sweden.

Goh, Y. N. (2015). Investigating revisit intentions for the boutique hotels of Penang - A UNESCO world heritage site. Asian Social Science, 11(4), 126-134.

Henderson, J. C. (2011). Hip heritage: The boutique hotel business in Singapore. Tourism and Hospitality Research, 11(3), 217-223.

Khosravi, S., Malek, A., \& Ekiz, E. (2014). Why tourists are attracted to boutique hotels: Case of Penang Island, Malaysia. Journal of Hospitality and Tourism, 12(1), 26 41.

Li, Y. (2003). Heritage tourism: The contradictions between conservation and change. Tourism and Hospitality Research, 4(3), 247-261.

Lim, M. W., \& Endean, M. (2009). Elucidating the aesthetic and operational characteristics of UK boutique hotels. International Journal of Contemporary Hospitality Management, 21(1), 38-51.

Lwin, M., \& Phau, I. (2013). Effective advertising appeals for websites of small boutique hotels. Journal of Research in Interactive Marketing, 7(1), 18-32.

Mcintosh, A. J., \& Siggs, A. (2005). An exploration of the experiential nature of boutique accommodation. Journal of Travel Research, 44(1), 74-81.

Olga, A. (2009, September). The alternative hotel market. International Conference on Management Science and Engineering. September 14-16, 2009, Moscow, Russia. 
Suraiyati Rahman

Emerging Built Heritage Commodification of Boutique Hotels in World Heritage Site: Evidence from George Town,

Penang, Malaysia

Prideaux, B. (2003). Commodifying heritage: loss of authenticity and meaning or an appropriate response to difficult circumstances? International Journal of Tourism Sciences, 3(1), 1-15.

Rani, P., Putri, C., \& Devina, A. (2017). Transforming heritage building for commercialisation. Planning Malaysia, 15(3), 135-146.

Rompho, N., \& Boon-itt, S. (2012). Measuring the success of a performance measurement system in Thai firms. International Journal of Productivity and Performance Management, 61(5), 548-562.

Rogerson, J. M. (2010). The boutique hotel industry in South Africa: Definition, scope, and organization. Urban Forum, 21(4), 425-439.

$\mathrm{Su}, \mathrm{X}$. (2011). Commodification and the selling of ethnic music to tourists. Geoforum, 42(4), 496-505.

Suraiyati, R. (2013). Heritage management challenges in historic town of Ludlow, England. World Applied Sciences Journal, 24(12), 1589-1596.

Teo, P., \& Yeoh, B. S. A. (1997). Remaking local heritage for tourism. Annals of Tourism Research, 24(1), 192-213.

Terzano, K. (2014). Commodification of transitioning ethnic enclaves. Behavioural Sciences, 4(4), 341-351.

Timothy, D. J., \& Teye, V. B. (2009). Tourism and the lodging sector. Oxford: Elsevier.

Van Hartesvelt, M. (2006). Building a better boutique hotel. Lodging Hospitality, 62(14), $32-44$.

Waitt, G. (2000). Consuming heritage. Annals of Tourism Research, 27(4), 835-862.

Wheeler, D. (2006). Understanding the value of boutique hotels (Master's thesis). Massachusetts Institute of Technology, USA.

Wight, P. (1994). Environmentally responsible marketing of tourism. In E. Carter \& G. Lowman (Eds.), Ecotourism: A Sustainable Option? London: Wiley.

Xu, K., Yan, T., \& Zhu, X. (2013). Commodification of Chinese heritage villages. Annals of Tourism Research, 40(1), 415-419

Received: $1^{\text {st }}$ June 2018. Accepted: $1^{\text {st }}$ December 2018 